Identity Crisis 
Also by Stephen Frosh

The Politics of Psychoanalysis

Psychoanalysis and Psychology

Child Sexual Abuse (with D. Glaser)

The Politics of Mental Health (with R. Banton, P. Clifford, F. Lousada and 7. Rosenthall) 


\section{Identity Crisis}

Modernity, Psychoanalysis and the Self

STEPHEN FROSH

palgrave 


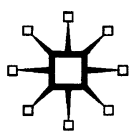

(c) Stephen Frosh 1991

All rights reserved. No reproduction, copy or transmission of this publication may be made without written permission.

No paragraph of this publication may be reproduced, copied or transmitted save with written permission or in accordance with the provisions of the Copyright, Designs and Patents Act 1988, or under the terms of any licence permitting limited copying issued by the Copyright Licensing Agency, 90 Tottenham Court Road, London W1T 4LP.

Any person who does any unauthorised act in relation to this publication may be liable to criminal prosecution and civil claims for damages.

The author has asserted his right to be identified as the author of this work in accordance with the Copyright, Designs and Patents Act 1988.

Published by PALGRAVE MACMILLAN

Houndmills, Basingstoke, Hampshire RG21 6XS and 175 Fifth Avenue, New York, N. Y. 10010

Companies and representatives throughout the world

PALGRAVE MACMILLAN is the global academic imprint of the Palgrave Macmillan division of St. Martin's Press, LLC and of Palgrave Macmillan Ltd. Macmillan ${ }^{\otimes}$ is a registered trademark in the United States, United Kingdom and other countries. Palgrave is a registered trademark in the European Union and other countries.

ISBN 978-0-333-51107-7

ISBN 978-1-349-21534-8 (eBook)

DOI 10.1007/978-1-349-21534-8

This book is printed on paper suitable for recycling and made from fully managed and sustained forest sources.

A catalogue record for this book is available from the British Library. 
To my parents 


\section{Contents}

Acknowledgements $\quad$ ix

Introduction 1

The Modern Mind $\quad 6$

Modernity, Narcissism and Psychosis 7

1 Social Experience 10

Modern Times 14

Postmodern States of Mind 21

2 Freud's Monster 32

The Dam Metaphor $\quad 33$

Nature and Unconscious Passion $\quad 40$

Affirmative Relations $\quad 42$

Bad World, Mad World 49

Postmodern Psychosis $\quad 53$

3 Narcissism 63

The Culture of Narcissism $\quad 63$

Subject and Object $\quad 68$

Narcissistic Pathology $\quad 73$

$\begin{array}{ll}\text { Lost Illusions } & 78\end{array}$

The Ego Ideal $\quad 81$

$\begin{array}{ll}\text { The Real Father } & 87\end{array}$

4 Narcissistic Pathology 95

Narcissism and Society $\quad 95$

Selfobjects and Mirrors. 101

The Raging Self 106

Broken Mirrors $\quad 113$

$\begin{array}{ll}\text { Transference and Change } & 119\end{array}$ 
viii

5 Dreaming of Madness 126

The Habit of Belief 126

The Influencing Machine 128

$\begin{array}{ll}\text { Schizoanalysis } & 137\end{array}$

The Madness of Self and Society 146

6 Psychotic States of Mind 152

Recuperating Reality 152

Signifying Nothing $\quad 159$

Inside and Out 163

Annihilatory Pieces 172

Postmodernism, Concrete Consumption and Reverie 179

Conclusion: The Crisis of Identity 187

$\begin{array}{ll}\text { Identity Crisis } & 187\end{array}$

Reverie and Resistance 191

References 196

Index 202 


\section{Acknowledgements}

Earlier and shorter versions of the chapters of this book have appeared in Free Associations, vol. 16, pp. 7-30 (1989), Free Associations, vol. 18, pp. 22-48 (1989) and in Human Relations (1990).

I would like to thank Daniel Miller for freely sharing some very productive ideas.

STEPHEN FROSH 